\title{
Identifikasi Faktor yang Mempengaruhi Siswa dalam Proses Pemilihan Jurusan Pendidikan Lanjutan (Studi pada Siswa Kelas XI SMA Negeri 5 Banda Aceh)
}

\author{
Zahra Nelissa $^{1}$, Sri Astuti ${ }^{2}$, Martunis ${ }^{3}$ \\ ${ }^{123}$ Universitas Syiah Kuala
}

\begin{abstract}
The factor in choosing a major for higher education for grade-11 students of Senior High School is the first step in preparing their future career. Before student continuing education to higher-education students has to determine the right major for his/herself. The factor that influence student in choosing the major in higher education is personality factor, a friend of the same age factor, and parent guidance factor. The purpose of this research is to determine the dominant factor that influences $11^{\text {th }}$ grade State Senior High School 5 of Banda Aceh students in the election process for major in advanced education. This research used descriptive qualitative as research approach. The total sample of this research is 138 students. The simple random sampling technique is used in obtaining the sample of this research. The data collection in this research is using a scale questionnaire. Based on the results of data analysis using the percentage of descriptive analysis, these research results indicate that there are two dominant factors affecting students in the election process for major in advanced education which is a personality factor with percentage of $92 \%$ and parent's factor with percentage of $76 \%$, meanwhile friend of the same age factor gives students insignificant influence in the election process for major in advanced education with percentage of $33 \%$. The conclusion in this research is the student of $11^{\text {th }}$ grade choose majors because the influence of personality factor and friend of the same age factor.
\end{abstract}

Keywords: selection of majors, further education

\section{PENDAHULUAN}

Setiap siswa yang memilih jurusan pendidikan lanjutan dilatar belakangi oleh berbagai faktor, dan memiliki pertimbangan yang berbeda-beda, namun ada beberapa faktor dominan yang akan mempengaruhi siswa dalam memilih jurusan. Secara garis besar terdapat dua faktor yang mempengaruhi siswa dalam memilih jurusan pendidikan lanjutan yaitu faktor intenal (dalam diri) dan faktor eksternal (luar diri). Faktor dalam diri yaitu karakteristik kepribadian (Zola, Ilyas \& Yusri, 20178) yang meliputi minat dan motivasi internal (Fitri, Ifdil, \& Neviyarni, 2016), sedangkan faktor luar diri adalah bimbingan orang tua dan kelompok teman sebaya. Keberhasilan seorang siswa dalam memilih dan menjalani perkuliahan sangat ditentukan oleh faktor dalam diri yaitu karakteristik kepribadian. Siswa yang memilih jurusan pendidikan lanjutan berdasarkan faktor dalam dirinya yaitu minat, motivasi internal, bakat serta kemampuan tanpa dipengaruhi oleh faktor luar yaitu orang tua dan kelompok teman sebaya, cenderung akan mencapai keberhasilan.

Siswa yang duduk di bangku Sekolah Menengah Atas (SMA) atau pendidikan sederajat umumnya akan melanjutkan pendidikan ke perguruan tinggi. Sebelum melanjutkan pendidikan ke perguruan tinggi, siswa-siswi di SMA harus terlebih dahulu memilih jurusan pendidikan yang tepat. Selain siswa kelas XII, siswa kelas XI juga harus mempersiapkan diriuntuk melanjutkan pendidikanSantrock (2007) menyatakan bahwa dalam menentukan lanjutan. 
Bukanlah perkara yang mudah. Terdapat berbagai hal yang harus dipikirkan dengan serius dan matang. Memilih secara terburu-buru tanpa memikirkan hal tertentu maka akan berdampak buruk bagi mahasiswa, seperti memilih jurusan yang tidak sesuai dengan bakatnya yang kadang kala menyebabkan dikeluarkannya seorang mahasiswa dari perguruan tinggi karena tidak dapat melakukan proses perkuliahan, bahkan dapat berujung terjadinya drop out (DO), berdasarkan studi penelitian awal yang didapatkan dari website data unsyiah.ac.id, dikemukakan bahwa mahasiswa angkatan 2010 mengalami DO karena tidak dapat menyelesaikan perkuliahan pada tahun 2017.

Fenomena pemilihan jurusan yang terjadi di kalangan siswa saat ini adalah banyaknya siswa yang memilih jurusan pendidikan lanjutan dikarenakan faktor luar diri, yaitu ikut-ikutan teman dan mengikuti pilihan orang tua tanpa didasari oleh bakat dan kemampuan diri. Siswa sebaiknya memilih jurusan berdasarkan faktor dalam diri, yaitu minat, motivasi internal dan bakat, serta kemampuan diri, karena menentukan arah karir adalah tanggung jawab diri sendiri. Menurut Liem dan Budi (2013) memilih jurusan pendidikan lanjutan dikarenakan teman sebaya dan orang tua akan menimbulkan berbagai masalah, seperti memperoleh pekerjaan dikarenakan tidak memenuhi kualifikasi dan skill yang dituntut oleh suatu pekerjaan.

Apabila keputusan dalam memilih suatu jurusan dibuat atas dasar diri individu, maka keputusan itu adalah keputusan yang terbaik. Sehingga ia dapat mencapai kesuksesan dalam menjalani perkuliahan. Begitu juga sebaliknya, jika memilih suatu jurusan karena faktor luar diri yaitu teman sebaya dan orang tua, maka siswa tersebut tidak dapat bertanggung jawab dengan masa depannya. Sejatinya membuat suatu keputusan yang melibatkan masa depan harus didasari pada pemahaman akan keputusan yang akan diambil, sama halnya dengan memilih jurusan. Jurusan yang dipilih karena faktor luar diri dapat memberikan dampak yang buruk pada siswa dimasa depan, seperti kuliah di jurusan yang tidak sesuai dengan kemampuan diri yang pada akhirnya menyebabkan prestasi menurun, bahkan dapat menyebabkan dikeluarkan mahasiswa tersebut dari suatu perguruan tinggi karena nilai yang dibawah rata-rata.

Merujuk pada pernyataan diatas maka penelitian ini mengkaji lebih dalam tentang "Identifikasi Faktor yang Mempengaruhi Siswa dalam Proses Pemilihan Jurusan Pendidikan Lanjutan".Tujuan penelitian ini yaituuntuk mengetahui faktor dominan mempengaruhi siswa dalam proses pemilihan jurusan pendidikan lanjutan pada siswa Kelas XI SMA Negeri 5 Banda Aceh.

\section{Faktor yang Mempengaruhi Siswa dalam Memilih Jurusan Pendidikan Lanjutan}

Memilih jurusan diperguruan tinggi merupakan langkah awal bagi siswa SMA untuk mempersiapkan masa depan. Menurut Agoes Dariyo (2004) menempuh pendidikan pada perguruan tinggi merupakan salah satu tahapan dari perkembangan karir yang telah memasuki fase eksplorasi dimana individu berusaha mencari pengalaman-pengalaman yang dibutuhkan guna menghadapi pekerjaan dimasa mendatang. Dalam mempersiapkan diri memasuki dunia kerja maka siswa yang duduk dibangku SMA harus memilih jurusan yang akan menjadi fokus ilmu. Berdasarkan teori yang dikemukakan oleh Agoes Dariyo (2004) seorang individu yang akan atau menempuh pendidikan ke perguruan tinggi merupakan suatu upaya perkembangan karir dimasa depan. Siswa SMA kelas XI yang akan melanjutkan pendidikannya ke perguruan tinggi harus memilih jurusan yang akan menjadi fokus ilmu. Memilih jurusan harus didasari oleh minat, bakat, motivasi dan kemampuannya karena keberhasilan karir siswa dimasa depan adalah tanggung jawab siswa itu sendiri. Oleh karena itu siswa SMA kelas XI memilih jurusan yang tepat yang sesuai dengan karakteristik kepribadiannya. Atmosudirdjo (2003) menyatakan bahwa dalam memilih jurusan pendidikan lanjutan, karena suatu pilihan jurusan pendidikan lanjutan yang didasarkan pada minat akan memicu siswa untuk berprestasi ketika berada di perguruan tinggi.

Dalam menentukan pilihan, individu dipengaruhi oleh beberapa faktor. Siswa SMA yang berada di masa dewasa awal memiliki tugas perkembangan yaitu memilih dan mempersiapkan pekerjaan (Duvall, 2011). Dalam mempersiapkan pekerjaan, individu cenderung melanjutkan pendidikan hingga ke perguruan tinggi sehingga memudahkan mendapatkan pekerjaan yang layak demi masa depannya. Menurut Berk (dalam Agoes Dariyo, 2004) pemilihan karir yang dilakukan oleh remaja dipengaruhi oleh faktor diri yaitu karakteristik kepribadian dan faktor luar diri yaitu kelompok teman sebaya dan bimbingan orang tua. Menurut Alwisol (2012) Kepribadian adalah karakteristik yang ada dalam diri individu yang melibatkan berbagai proses psikologis. Aspek kepribadian meliputi minat, motivasi, emosi, sikap, dan penyesuaian diri. Terdapat berbagai aspek yang mempengaruhi siswa dalam proses pemilihan jurusan pendidikan lanjutan, namun yang akan dibahas dalam penelitian ini adalah aspek minat dan aspek motivasi dalam diri seseorang yang memiliki kaitan dalam memilih suatu jurusan. Menurut Djaali (2008) minat jurusan adalah kecenderungan seseorang untuk memilih jurusan tertentu yang sesuai dengan karakteristik kepribadiannya. 
Selanjutnya faktor luar diri yang mempengaruhi siswa dalam pemilihan jurusan pada penelitian ini adalah faktor kelompok teman sebaya dan faktor orang tua. Menurut Santrock (2007) kelompok teman sebaya adalah kelompok yang terdiri dari dua atau lebih remaja yang memiliki usia relatif sama dan saling berinteraksi satu sama lain. Santosa Slamet (2006) mengemukakan bahwa teman sebaya memberikan pengaruh besar pada remaja, hal ini disebabkan karena di dalam kelompok teman sebaya telah terbentuk nilai-nilai yang mempengaruhi tingkah laku, minat, sikap dan fikiran remaja disamping adanya pengaruh kuat dari orang tua. Hurlock (2011) juga berpendapat bahwa kelompok teman sebaya dapat mempengaruhi remaja, karena dalam kelompok teman sebaya, remaja akan saling memberikan informasi tentang peranan-peranan sosial sehingga akan saling mempengaruhi untuk mencapai tujuan yang sama. Besarnya pengaruh kelompok teman sebaya disebabkan oleh intensitas waktu kebersamaan antara remaja dengan teman sebaya.

Selain faktor teman sebaya, faktor orang tua juga ikut memberikan pengaruh pada siswa dalam memilih jurusan. Gunawan (2010) menyatakan orang tua memberikan pengaruh dalam proses pendidikan anak, sehingga baik buruknya prestasi anak dapat ditentukan oleh bimbingan yang diberikan orang tua. Orang tua membimbing anak agar dapat meraih kesuksesan di masa depan yang sesuai dengan harapan orang tua. Carole Wade \& Carol Tavris (2007) juga berpendapat bahwa bimbingan orang tua memberikan pengaruh yang signifikan dalam proses pemilihan jurusan pendidikan lanjutan. Semakin besar pengaruh orang tua dalam membimbing, maka siswa akan cenderung memilih jurusan yang diarahkan oleh orang tua. Bimbingan orang tua akan menjadi suatu pertimbangan bagi siswa ketika memilih jurusan pendidikan lanjutan.

\section{METODE}

Penelitian ini menggunakan pendekatan kuantitatif. Tipe Penelitian ini ialah penelitian deskriptif. Penelitian deskriptif dalam penelitian ini bertujuan untuk mendapatkan gambaran dan keterangan tentang faktor yang mempengaruhi siswa dalam pemilihan jurusan pendidikan lanjutan. Penelitian ini dilaksanakan di SMA Negeri 5 Banda Aceh. Populasi penelitian ini adalah siswa kelas XI SMA Negeri 5 Banda Aceh tahun ajaran 2017/2018 yang berjumlah 212 siswa. Sampel penelitian ini adalah siswa kelas XI. Kelas XI terdiri dari 8 kelas yang berasal dari jurusan IPA dan IPS. Jurusan IPA berjumlah 5 kelas dan jurusan IPS berjumlah 3 kelas. Teknik Pengumpulan data dalam penelitian ini menggunakan angket skala likert. Skala sikap dari Likert disusun dalam bentuk pernyataan untuk dinilai oleh responden, apakah pernyataan itu didukung atau ditolaknya, melalui rentangan nilai tertentu. Dalam penelitian ini peneliti juga menentukan kategori pada variabel dan sub variabel penelitian. Penggunaan rumus norma kategori yang diawali dengan menentukan skor tertinggi, skor terendah, rata-rata keseluruhan dan standar deviasi. Peneliti menggunakan 5 istilah dalam mengkategorikan persepsi responden, yaitu Sangat Tidak Baik (STB), Tidak Baik (TB), Cukup Baik (CB), Baik (B), Sangat Baik (SB).

Tabel 1. Rumus Norma Kategori

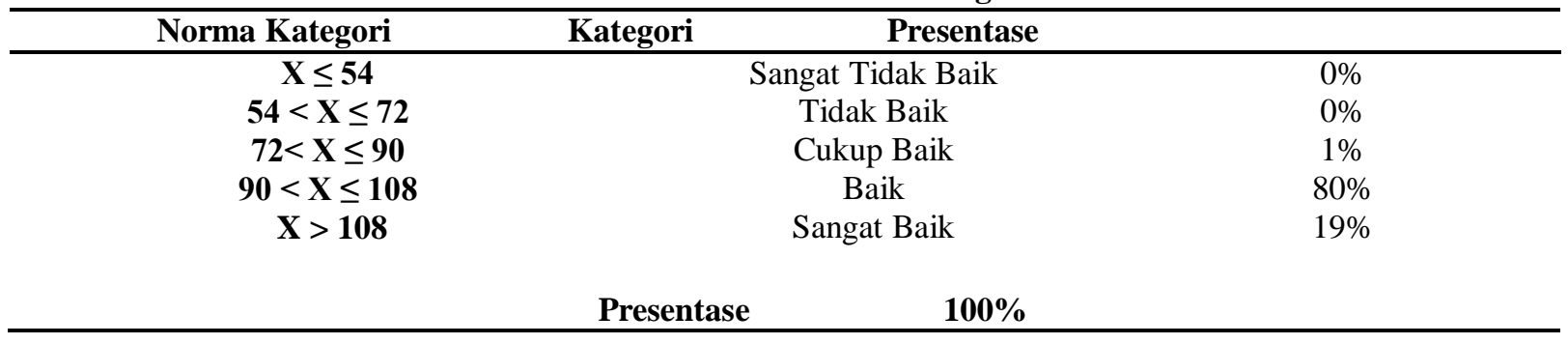

Berdasarkan tabel diatas, dari total 138 siswa yang mengisi angket, hanya $1 \%$ siswa yang berada pada kategori cukup, karena memiliki rentangan nilai antara 72 sampai 90, dan terdapat 80\% berada pada kategori baik, karena memiliki rentangan nilai antara 90 sampai 108, serta terdapat $19 \%$ siswa berada pada kategori sangat baik, karena memiliki rentangan nilai lebih dari 108.

\section{HASIL}

Pelaksanaan penelitian ini diawali dengan menyusun kisi-kisi yang kemudian dijadikan sebagai instrumen penelitian yaitu angket yang digunakan sebagai alat ukur. Sebelum digunakan dalam pelaksanaan penelitian, angket terlebih dahulu di uji cobakan untuk memperoleh item-item yang valid dan reliabel. Jumlah item pernyataan pada angket penelitian ini yaitu 38 butir pernyataan. Berdasarkan hasil uji validitas terhadap 38 butir penyataan, maka didapati 27 butir pernyataan valid. Uji reliabilitas instrumen penelitian menunjukkan bahwa data yang diperoleh berada pada kriteria reliabilitas sangat tinggi yaitu 0,718 . Hasil penelitian ini dapat dilihat berdasarkan hasil analisis instrumen penelitian yaitu variabel dan subvariabel. Penelitian ini dilakukan untuk 
mengetahui faktor-faktor yang mempengaruhi siswa kelas XI SMA N 5 Banda Aceh dalam proses pemilihan jurusan pendidikan lanjutan. Pada penelitian ini peneliti menetukan data hipotetik. Hasil data hipotetik dari 27 butir item pernyataan diperoleh skor tertinggi adalah 135 sedangkan skor terendah adalah 27, dengan skor ratarata keseluruhan adalah 81 dan standar deviasi sebesar 18.

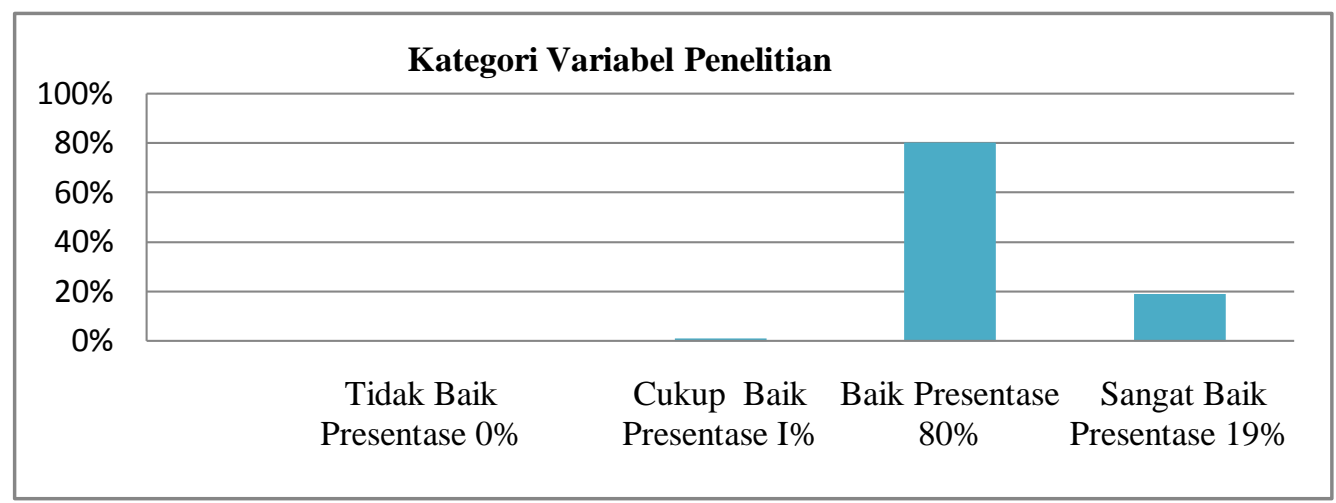

Gambar 1. Kategori Variabel Penelitian

Berdasarkan gambar diatas, terdapat 5 kategori dalam menafsikan hasil penelitian, yaitu kategori sangat tidak baik dan tidak baik dengan presentase $0 \%$, kategori cukup baik dengan presentase $1 \%$, dan kategori baik dengan presentase $80 \%$, serta kategori sangat baik dengan presentase $19 \%$. Penyusunan tabel kategori variabel penelitian ini dimaksudkan untuk mempresentasikan distribusi skor subjek penelitian secara umum dan melihat kcenderungan skor subjek.

Penelitian ini terdiri dari beberapa variabel yaitu faktor kepribadian, faktor teman sebaya, faktor orang tua dan faktor pengambilan keputusan dalam memilih jurusan pendidikan lanjutan. Berikut hasil presentase masing-masing faktor dalam penelitian ini.

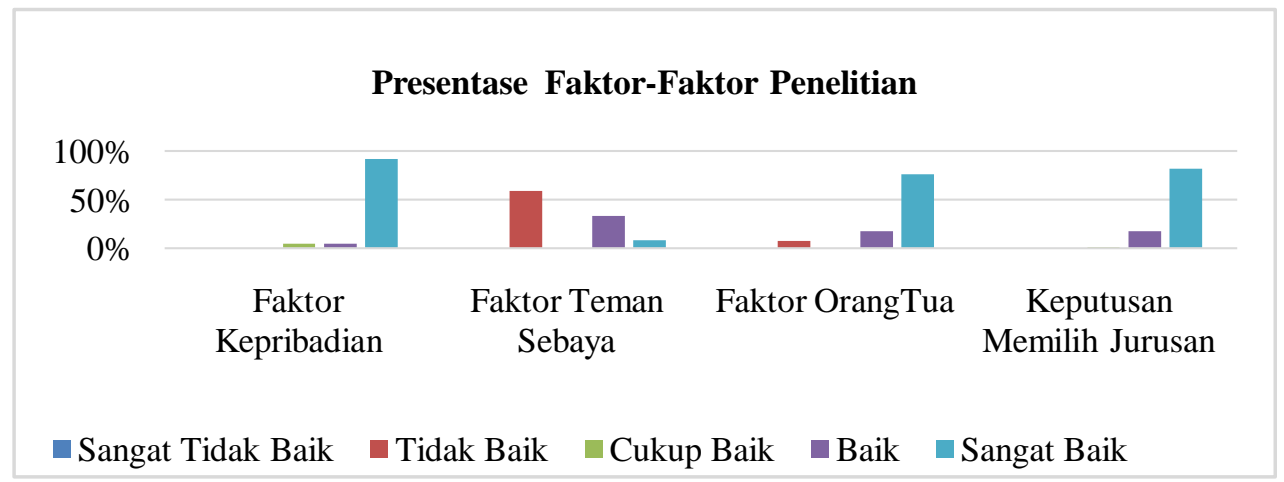

Gambar 2. Presentase Faktor-Faktor Penelitian

Berdasarkan gambar diatas, maka diketahui bahwa hasil data hipotetik faktor kepribadian diperoleh skor tertinggi sebesar 30 sedangkan skor terendah yaitu 6, dan skor rata-rata keseluruhan sebesar 18. Serta standar deviasi yaitu 4. Data menunjukkan bahwa $4 \%$ siswa menyatakan faktor kepribadian cukup mempengaruhi mereka dalam pemilihan jurusan, lalu 4\% lainnya menyatakan berpengaruh, sedangkan $92 \%$ lainnya menyatakan bahwa faktor kepribadian sangat mempengaruhi dirinya dalam memilih jurusan. Berdasarkan data tersebut diketahui bahwa faktor kepribadian memberikan pengaruh besar pada siswa kelas XI dalam proses memilih jurusan pendidikan lanjutan.

Hasil data hipotetik faktor kelompok teman sebaya diperoleh skor tertinggi sebesar 40 sedangkan skor terendah yaitu 8, dan skor rata-rata keseluruhan sebesar 24, serta standar deviasi yaitu 5.33. Data menunjukkan bahwa 59\% memilih jurusan tanpa pengaruh teman sebaya, hanya 33\% siswa yang dipengaruhi oleh teman sebaya, sedangkan $8 \%$ lainnya memilih jurusan karena sangat dipengaruhi oleh faktor teman sebaya. Dari pemaparan ini menunjukkan bahwa faktor kelompok teman sebaya memiliki pengaruh kecil pada siswa kelas XI dalam proses memilih jurusan pendidikan lanjutan. 
Hasil data hipotetik faktor orang tua diperoleh skor tertinggi sebesar 30 sedangkan skor terendah sebesar 6, dan rata-rata keseluruhan yaitu 18, serta standar deviasi yaitu 4. Data menunjukkan bahwa 7\% siswa memilih jurusan tanpa pengaruh orang tua, selain itu 17\% lainnya berpengaruh, sedangkan $76 \%$ lainnya sangat berpengaruh. Berdasarkan data tersebut diketahui bahwa faktor orang tua memiliki pengaruh yang besar pada siswa kelas XI dalam proses memilih jurusan pendidikan lanjutan.

Hasil data hipotetik keputusan memilih jurusan diperoleh skor tertinggi sebesar 35, sedangkan skor terendah yaitu 7, dan rata-rata keseluruhan yaitu 21, serta standar deviasi sebesar 4.66. Variabel keputusan pemilihan jurusan ini disusun oleh peneliti untuk melihat faktor-faktor yang dominan mempengaruhi siswa dalam memilih jurusan. Berdasarkan jawaban siswa, hasil menunjukkan bahwa faktor dominan yang mempengaruhi siswa dalam memilih jurusan adalah faktor kepribadian dan faktor orang tua.

Hasil data hipotetik diatas menunjukkan bahwa Faktor kepribadian dan faktor orangtua sangat berpengaruh dalam proses pemilihan jurusan, hal ini terlihat dari tingginya presentase yang diperoleh. Faktor kepribadian memiliki presetase $92 \%$ dan faktor orang tua memiliki presentase $76 \%$, artinya terdapat pengaruh yang dominan antara faktor kepribadian dan faktor orang tua pada siswa kelas XI SMA Negeri 5 Banda Aceh dalam proses pemilihan jurusan pendidikan lanjutan.

\section{PEMBAHASAN}

Faktor-faktor yang mempengaruhi siswa dalam proses memilih jurusan pendidikan lanjutan pada siswa kelas XI SMA Negeri 5 Banda Aceh menunjukkan bahwa faktor yang dominan mempengaruhi siswa kelas XI dalam proses memilih jurusan pendidikan lanjutan adalah faktor kepribadian dan faktor orang tua, sedangkan faktor teman sebaya memiliki pengaruh kecil pada siswa dalam memilih jurusan pendidikan lanjutan. Faktor kepribadian memiliki presentase $92 \%$ dan orang tua memiliki presentase $76 \%$ yang artinya faktor kepribadian dan faktor orang tua memberikan pengaruh besar bagi siswa dalam proses memilih jurusan pendidikan lanjutan, sedangkan faktor teman sebaya memiliki presentase 33\%, artinya faktor teman sebaya memiliki pengaruh kecil pada siswa kelas XI dalam proses memilih jurusan pendidikan lanjutan.

Hasil angket menunjukkan bahwa siswa memilih jurusan karena adanya minat dan motivasi internal yang melatarbelakangi keputusan dalam memilih suatu jurusan, hasil penelitian ini sesuai dengan pernyataan yang dikemukakan oleh Dariyo (2004) bahwa hal-hal yang berkaitan dengan karakteristik kepribadian individu dapat mempengaruhi seseorang dalam memilih jurusan pendidikan lanjutan seperti bakat, minat, motivasi dan intelektual.

Pada faktor orang tua, siswa memilih jurusan tertentu karena adanya peran orang tua dalam membimbing dan memberikan pendapat akan jurusan yang dianggap oleh orang tua memiliki prospek kerja yang besar dimasa yang akan datang. Sesuai dengan teori yang dikemukakan oleh Carole Wade \& Carol Tavris (2007) bahwa orang tua dapat memberikan pengaruh pada anaknya dalam bidang minat, intelektual dan pendidikan. Pengaruh orang tua pada pendidikan anaknya dapat dilihat dari kecenderungan orang tua yang memilih jurusan yang dinilai baik bagi anaknya dan memiliki prospek kerja yang besar, sehingga anak mendapatkan kesuksesan dimasa depan.

Pada penelitian ini, faktor teman sebaya memiliki pengaruh yang kecil pada siswa dalam memilih jurusan pendikan lanjutan pada siswa SMA Negeri 5 Banda Aceh. Dari item angket yang diisi oleh siswa terkait faktor teman sebaya, diketahui bahwa siswa tidak setuju jika teman sebaya memberikan pengaruh dalam memilih jurusan pendidikan lanjutan, hanya sebagian kecil saja siswa yang setuju jika teman sebaya memberikan pengaruh dalam memilih jurusan pendidikan lanjutan. Menurut Santosa Slamet (2006) kelompok teman sebaya memberikan pengaruh terhadap tingkah laku, minat siswa, namun hasil penelitian ini menunjukkan bahwa kelompok teman sebaya memiliki pengaruh kecil pada siswa kelas XI dalam memilih jurusan pendidikan lanjutan. Faktor teman sebaya yang peneliti anggap di hipotesis mempengaruhi siswa kelas XI dalam proses memilih jurusan pendidikan lanjutan ternyata tidak dapat dibuktikan melalui penelitian ini. Berdasarkan data angket yang diisi oleh siswa memperlihatkan bahwa faktor teman sebaya tidak mempengaruhi siswa dalam proses memilih jurusan pendidikan lanjutan. Meskipun secara psikologis siswa memiliki hubungan keakraban dengan teman sebayanya yang menimbulkan kesamaan minat, sikap, namun ternyata hal ini tidak sepenuhnya menjadi pertimbangan siswa dalam memilih jurusan pendidikan lanjutan.

Faktor teman sebaya dalam penelitian ini memang memiliki pengaruh kecil pada siswa dalam keputusan memilih jurusan pendidikan lanjutan, karena sejatinya memilih jurusan pendidikan lanjutan adalah tanggung jawab pribadi siswa, dimana siswa harus dapat memutuskan sendiri jurusan yang diinginkannya, sehingga 
jurusan tersebut dapat menjadi menjadi fokus ilmu ketika melanjutkan pendidikan ke perguruan tinggi. Keberhasilan siswa dalam melanjutkan pendidikan tidak tergantung pada orang lain walau teman dekat sekalipun. Meskipun pada penelitian ini kelompok teman sebaya memiliki pengaruh kecil dalam proses memilih jurusan pendidikan lanjutan, namun kelompok teman sebaya dapat menjadi tempat bagi siswa untuk berbagi cerita.

Setelah melewati proses analisis instrumen penelitian maka dapat disimpulkan bahwa tiga faktor yang peneliti duga mempengaruhi siswa dalam memilih jurusan pendidikan lanjutan, yaitu faktor kepribadian, faktor kelompok teman sebaya dan faktor orang tua, namun hasil menunjukkan bahwa faktor kepribadian dan faktor orang tua memberikan pengaruh dominan pada siswa dalam memilih jurusan pendidikan lanjutan sedangkan faktor teman sebaya memberikan pengaruh kecil pada siswa dalam memilih jurusan pendidikan lanjutan.

\section{KESIMPULAN}

Berdasarkan temuan dan pembahasan hasil penelitian, maka dapat dikemukakan kesimpulan sebagai berikut: 1) Faktor kepribadian memiliki pengaruh yang besar pada siswa dalam memilih jurusan, Faktor kepribadian berada pada kategori sangat baik presentase 92\%. Faktor kepribadian menunjukkan bahwa siswa memilih jurusan pendidikan lanjutan disebabkan oleh adanya minat terhadap jurusan dan motivasi internal; 2) Faktor bimbingan orang tua memiliki pengaruh yang besar pada siswa dalam memilih jurusan. Faktor bimbingan orang tua berada pada kategori baik presentase $76 \%$. Hasil penelitian menunjukkan bahwa siswa cenderung memilih jurusan karena bimbingan orang tua; 3) Faktor teman sebaya memiliki pengaruh kecil pada siswa dalam memilih jurusan. Faktor teman sebaya berada pada kategori tidak baik presentase 33\%. Hasil penelitian menunjukkan bahwa pemilihan jurusan tidak sepenuhnya factor teman sebaya.

\section{DAFTAR RUJUKAN}

Atmosudirdjo, Prajudi. (2003). Teori Administrasi. Jakarta: STIALAN

Carole Wade dan Carol Tavris. (2007). Psikologi, Alih Bahasa Widyasinta. Jakarta: Erlangga.

Dariyo, Agoes. (2004). Psikologi Perkembangan Dewasa Muda. Jakarta: Grasindo.

Departemen Pendidikan Nasional. Undang-Undang Nomor 20 Tahun 2003 tentang Sistem Pendidikan Nasional. Jakarta: BP Dharma Bhakti.

Djaali. (2008). Skala likert. Jakarta: Pustaka Utama.

Duvall, E.M. (2011). Marriage and Family Development. New York: Harper Roe

Fitri, E., Ifdil, I., \& Neviyarni, S. (2016). Efektivitas layanan informasi dengan menggunakan metode blended learning untuk meningkatkan motivasi belajar. Jurnal Psikologi Pendidikan dan Konseling: Jurnal Kajian Psikologi Pendidikan dan Bimbingan Konseling, 2(2), 84-92.

Gunawan Ary H. (2010). Sosiologi Pendidikan: Suatu Analisa Sosiologi Tentang

BerbagaiProblem Pendidikan: Jakarta: Rineka Cipta

Hurlock, Elizabeth B. (2011). Psikologi Perkembangan: Suatu Pendekatan Sepanjang RentangKehidupan, Erlangga: Jakarta

Jeffrey. (2008). Psikologi Abnormal. Erlangga: Jakarta

Liem dan Budi. (2013). 7 Jurusan Bergaji Besar. Yogyakarta: Diandra Primamitra

Margono. (2010). Metodologi Penelitian Pendidikan. Jakarta: Rineka Cipta

Santosa, Slamet. (2006). Dinamika Kelompok. Jakarta: Bumi Aksara

Santrock, J W. (2007). Remaja Edisi 11 Jilid 2. Jakarta : Erlangga

Sugiyono. (2005). Metode Penelitian Administrasi. Bandung: Alfabeta.

Sugiyono. (2008). Metode Penelitian kuantitatif kualitatif dan R\&D. Bandung: CV Alvabeta

Zola, N., Ilyas, A., \& Yusri, Y. (2017). Karakteristik Anak Bungsu. Jurnal Konseling dan Pendidikan, 5(3), 109-114. 